http://dx.doi.org/10.12775/szhf.2013.043

\title{
Magdalena Kozak, Problem zła w filozofii Emmanuela Levinasa, Wydawnictwo Naukowe Uniwersytetu Papieskiego Jana Pawła II w Krakowie, Kraków 2011, ss. 298.
}

Emmanuel Levinas jest jednym z oryginalniejszych myślicieli XX wieku, nie dziwi więc fakt, że poświęcono mu bardzo wiele rozpraw. Jego spuścizna pisarska prezentuje się bogato, a od publikacji jego ostatniego głównego działa filozoficznego (Inaczej niż być lub ponad istota, 1974) upłynęło niedużo czasu. Po tymże dziele ukazały się jeszcze wykłady Levinasa wygłoszone na uniwersytecie w Sorbonie (Bóg, śmierć i czas, 1993), wywiady (najbardziej znany to Etyka i nieskończony, 1982) oraz inne pomniejsze prace, które niewątpliwie również należy uwzględnić podejmując próbę interpretacji filozofii tego trudnego w lekturze i rozumieniu autora. $\mathrm{Z}$ tego względu zainteresowanie filozofią Levinasa utrzymuje się na świecie, nie wyłączając Polski, cały czas na równie wysokim poziomie, czego efekty możemy obserwować na rynku wydawniczym.

Niczym osobliwym jest stwierdzenie, że centralnym problemem filozofii Levinasa, poczynając zwłaszcza od okresu jego twórczości zapoczątkowanej przez Całość i nieskończoność, jest problem Dobra. Z tego względu nie sposób, by uwagi czytelnika, zainteresowanego myślą Levinasa, uszła praca poświęcona lustrzanemu odbiciu tegoż zagadnienia mianowicie kwestii zła. Zagadnienie zła w myśli Levinasa, dotychczas zaniedbywane, pomijane i z rzadka jedynie poruszane w literaturze przedmiotowej, zostało podjęte przez Magdalenę Kozak w książce Problem zła w filozofii Emmanuela Levinasa. Pozycja ta ukazała się w 2011 roku nakładem Wydawnictwa Naukowego Uniwersytetu Papieskiego Jana Pawła II w Krakowie i stanowi rezultat badań dr Magdaleny Kozak prowadzonych w ramach pracy doktorskiej na wyżej wspomnianej uczelni. Praca badawcza była realizowana pod opieką 
prof. Aleksandra Bobko, któremu również zagadnienie zła nie jest obce. Jest on autorem publikacji na ten temat w filozofii Kanta oraz Tischnera ${ }^{1}$.

Książka Magdaleny Kozak jest pierwszym na gruncie polskim, samodzielnym i całościowym opracowaniem tematu zła w filozofii Levinasa, z tego względu jej pojawienie się wzbudziło niewątpliwie pozytywną reakcję i ogromne zainteresowanie czytelników francuskiego filozofa. $Z$ tych samych powodów publikacja nie uniknęła zapewne zmierzenia się ze znacznymi oczekiwaniami w niej pokładanymi. Cóż bowiem można powiedzieć o złu w filozofii, którą można nazwać filozofią Dobra? Otóż wcale niemało, jak dowodzi lektura książki. Co więcej, problem zła okazuje się u Levinasa ściśle związany z problemem Dobra.

Mimo że na plan pierwszy w filozofii Levinasa wysuwa się kategoria Dobra, to niewątpliwie myśliciel jest uwikłany $\mathrm{w}$ problem zła przynajmniej $\mathrm{w}$ aspekcie biograficznym. Był on bowiem świadkiem takiego rodzaju zła, które wstrząsnęło ludzką świadomością, stanowiąc wyraz porażki i załamania się Europejskiej kultury. Oczywiście mowa jest tu o Holokauście, w wyniku którego zginęła prawie cała rodzina filozofa. Doświadczenia II wojny światowej wpłynęły na Levinasa tak silnie, że do dziś toczą się spory wśród badaczy na temat zakresu i roli tego oddziaływania oraz zasadności uwzględniania go przy dokonywaniu interpretacji, obrony, jak również krytyki jego filozofii. Potwierdzają to słowa samego filozofa, który w Trudnej wolności napisał, że jego biografia jest owładnięta przeczuciem i wspomnieniem okropności nazizmu².

Książka Magdaleny Kozak została podzielona na pięć głównych rozdziałów. Dwa pierwsze: Korzenie Levinasowskiej wizji zła oraz Kontekst historycz$n y$ są przedstawieniem problemu zła w filozofii Levinasa $\mathrm{z}$ bardzo szerokiej perspektywy, obejmując w swoim opisie zarówno wspomniane już historyczne doświadczenia filozofa, jak i filozoficzno-religijne inspiracje, jakie miały wpływ na formułowanie się Levinasa refleksji na temat zła. W książce obecne są odniesienia do filozofów, którzy mieli niezaprzeczalny wpływ na kształtowanie się filozofii Levinasa w ogóle, takich jak Kartezjusz, Kant, Hegel czy Heidegger. Zaletą pracy Magdaleny Kozak jest jednak rezygnacja z tradycyjnego omawiania dobrze już znanych związków myśli Levinasa z powyższymi

${ }^{1}$ A. Bobko, Myślenie wobec zła. Polityczny i religijny wymiar myślenia w filozofii Kanta i Tischnera, Instytut Myśli Tischnera, Kraków 2007.

${ }^{2}$ E. Levinas, Trudna wolność. Eseje o judaizmie, tłum. A. Kuryś, Gdynia 1991. 
filozofami, takie bowiem odwołania możemy odnaleźć już w niejednej pozycji z literatury przedmiotu. Autorka przywołuje powyższych klasyków filozofii w kontekście ich, niekiedy wcale nie wyrażonego przez Levinasa explicite, wpływu na kształtowanie się wizji zła w jego twórczości. Trzeba zauważyć, że nie zawsze są to powiązania oczywiste, lecz odważne, przedstawione z dużym rozmachem, opierające się niejednokrotnie na skojarzeniach i otwartych pytaniach, rodzących się pod wpływem zestawienia analiz klasyków z koncepcją zła u Levinasa. Mimo że niejeden skwapliwy historyk filozofii miałby ochotę podać $\mathrm{w}$ wątpliwość powyższą formę przeprowadzonych analiz porównawczych, posiadają niezaprzeczalną zaletę. Pozwalają mianowicie wyjść poza suche historyczno-rekonstrukcyjne ramy omawianego problemu i otwierają perspektywę myślenia o złu już nie tylko na poziomie filozofii samego Levinasa, lecz również w wymiarze uniwersalnym, zawierającym pewną prawdę, do którego przecież w istocie dąży każda myśl i refleksja.

Rozdział drugi, który umieszcza proces kształtowania się myśli Levinasa na temat zła w kontekście historycznym, porusza pytanie, szeroko dyskutowane po II wojnie światowej, dotyczące potrzeby lub konieczności mówienia albo wręcz przeciwnie, zamilknięcia wobec Holokaustu - najdotkliwszego objawienia się zła w ludzkiej historii. Stanowisko, które zajął Levinas w tym sporze głosi, w przeciwieństwie do tego, co postulował np. Adorno, że nie tylko można, lecz wręcz należy o nim mówić, milczenie bowiem oznaczałoby zapomnienie, a o tym zapomnieć nie wolno. Nie tylko ze względu na szacunek dla tych, którzy tego zła doświadczyli, lecz również ze względu na potrzebę zapobieżenia powtórzeniu się historii w przyszłości.

Magdalena Kozak rekonstruuje również stanowisko Levinasa dotyczące genezy zła dziejowego, a dokładnie II wojny światowej oraz nazizmu, starające się odsłonić logiczny porządek i właściwy sens, który wyłonił się z konkretnych wydarzeń historycznych, prowadząc nieuchronnie do wyżej wspomnianych tragedii. Praca prezentuje więc Levinasowskie refleksje na temat historycznych przejawów zła, takich jak rasizm, antysemityzm, hitleryzm dążące w sposób filozoficzny do odsłonięcia ich znaczenia, sensu oraz moralnych konsekwencji. Warto zaznaczyć, że Levinas wykazywał się wnikliwą i trafną intuicją w kwestii hitleryzmu już od samego początku jego formułowania się, czego dał wyraz między innymi w tekście z Kilka myśli o filozofii hitleryzmu w 1933 r., opublikowanym dzień po dojściu Hitlera do władzy.

Wreszcie rozdział drugi podejmuje również kwestię, której nie można przemilczeć, jeśli bada się myśl Levinasa dotyczącą historycznego zła, jakim 
była II wojna światowa i towarzyszący jej Holokaust. Jest nim mianowicie stosunek filozofa do tej zachodniej tradycji filozoficznej, którą reprezentują przede wszystkim Hegel oraz Heidegger. To właśnie myślenie w kategoriach całości i systemu, które mają realizować się w historii, ignorując jednak indywidualność i jednostkowość - jak postrzega filozofię Hegla Levinas - miało doprowadzić człowieka zachodu do postawy przyzwalającej na wojnę. Według Levinasa w systemie Hegla nieuniknionym momentem umożliwiającym rozwój dziejów i będącym jednocześnie wyrazem naturalnej walki między Panem a Niewolnikiem jest wojna. Jeśli taki stan, w którym relacje międzyludzkie są oparte na dążeniu do dominacji, są naturalne, normalne oraz właściwe, to wojna, będąca ich wyrazem i konsekwencją, również jest jak najbardziej naturalna i wręcz nieunikniona. Perspektywa ta połączona $\mathrm{z}$ myśleniem ontologicznym, w specyficznym Levinasowkim rozumieniu, którego najpełniejszy wyraz upatruje on w filozofii Heideggera. To właśnie Heideggerowski sposób rozumienia bycia, które dąży do prawdy istnienia poprzez rozszerzanie swojej przestrzeni życiowej za wszelką cenę, nie licząc się z byciem innych, zdaniem Levinasa, ukształtowało realizację zbrodniczej, nazistowskiej polityki.

Rozdziały kolejne, zatytułowane: Zło $w$ strukturze Toż-Samego oraz Zło $w$ strukturze Toż-Samy - Inny (zło relacyjne) rekonstruują problematykę zła obecną we „właściwej” już filozofii zaprezentowanej w głównych dziełach Levinasa, jakimi są: Całość i nieskończoność oraz Inaczej niż być lub ponad istotą. Są to zarazem najbardziej dyskusyjne części książki, które mogą wzbudzać wątpliwości wokół zaprezentowanej przez autorkę rekonstrukcji Levinasowskiej wizji zła.

Według autorki Levinas sytuuje zło w dwóch wymiarach, a właściwie w dwóch rodzajach relacji, w które wchodzi człowiek. Pierwszy wymiar Magdalena Kozak odnosi do konstytucji samego podmiotu, czyli Toż-Samego, w strukturze którego ma się kryć zło. Sposób egzystencji podmiotu i jego odniesienie do siebie samego, czyli pierwszy rodzaj relacji, w którą miałby zdaniem autorki ujmować Levinas jako przestrzeń etyczną. Taka teza pojawia się we wstępie do trzeciego rozdziału, jednak dalsze analizy nie potwierdzają jej w pełnym stopniu.

Magdalena Kozak opisuje proces kształtowania się podmiotowości, począwszy od wyłonienia się hipostazy z anonimowego il $y a$, mające wyrażać istnienie bez istniejącego, czyli samo bycie, które ewidentnie ma dla Levinasa negatywny wymiar poprzez jego nieusuwalność, nieosobowy i nieokreślony 
charakter. Słusznie zauważa, że il y a stanowi niszczycielską siłę i jest pewnym rodzajem zła, które czyha na podmiot, grożąc usunięciem się w nie. Istniejący, czyli hipostaza musi jednak ciągle zmagać się ze swoim własnym istnieniem, które okazuje się być nieznośnym i bezsensownym ciężarem, a jego nieszczęśliwą kondycję ukazują takie fenomeny, jak: znużenie, zmęczenie i lenistwo. Charakterystycznym dla tych trzech modusów bycia ma być moment odmowy zwrócony w stronę istnienia, które chociaż jest ciągłym dzianiem się i troszczeniem się - używając języka Heideggera - nie posiada sensu. Magdalena Kozak trafnie podkreśla nieszczęście i cierpienie, które widzi Levinas w takim rodzaju istnienia, stanowiące w interpretacji autorki przejaw zła obecny już na samym poziomie konstytucji podmiotowości. Czy można jednak nazwać takie zło moralnym?

Dyskusyjnym wydaje się nazywanie zła pojawiającego w tym wymiarze złem stricte moralnym. Owszem, może ono stanowić podstawę, czy też wręcz konieczny warunek do zaistnienia zła w sensie moralnym, objawiającym się i dającym o sobie znać w spotkaniu z drugim człowiekiem. Zło w strukturze Toż-Samego bardziej przypomina zło metafizyczne, idąc za właściwie klasycznym podziałem rodzajów zła dokonanym przez Leibniza. Spełnia bowiem jego kluczowe cechy - jest niezawinione, wypływa z pewnej niedoskonałości zawartej w konstytucji podmiotu, na którą on sam nie ma jednak wpływu. Sama Magdalena Kozak również, podsumowując rozdział trzeci, wyraża wątpliwości co do tego, czy słusznie można mówić tu o złu, czy raczej o nieszczęściu, z którym musi zmagać się Toż-Samy. W interpretacji autorki Levinas ma rozpatrywać to nieszczęście w charakterze etycznym, co jednak nie znajduje potwierdzenia w samej rekonstrukcji wizji zła na poziomie struktury Toż-Samego zaprezentowanej w pracy. Magdalena Kozak nie wskazuje bowiem momentów w filozofii Levinasa, w których filozof miałby utożsamiać ten rodzaj zła ze złem moralnym.

Więcej znamion zła moralnego można odnaleźć niewątpliwie w wolności ontologicznej, którą w koncepcji Levinasa obdarzony jest podmiot. To przecież między innymi ona umożliwia zło moralne, bo spowodowane działaniami człowieka w stosunku do drugiego człowieka i jest przyczyną egoizmu i imperializmu Toż-Samego. Magdalena Kozak podejmuje te aspekty w swojej pracy, jednak akcentuje fakt, że wolność ontologiczna, egoizm i imperializm sprowadzają na człowieka samotność. Ta z kolei rodzi cierpienie i nieszczęście, jest zatem wyrazem zła raczej w sensie metafizycznym, wypływającym bowiem z niedoskonałej konstytucji Toż-Samego. 
W rozdziale czwartym autorka prezentuje objawianie się zła według Levinasa $\mathrm{w}$ przestrzeni ściśle moralnej, ponieważ powstałej dzięki spotkaniu Toż-Samego z drugim człowiekiem, czyli Innym. Dzięki spotkaniu w epifanii twarzy zawiązuje się relacja, dlatego też zło, które tutaj może wystąpić Magdalena Kozak nazywa złem relacyjnym. Problem zła moralnego w koncepcji Levinasa został w książce przedstawiony jako ściśle powiązany z Dobrem. Chociaż epifania twarzy otwiera na Transcendencję i zarazem na bycie dobrym, zawiera jednak wymiar prowadzący do zła. W twarzy Innego tkwi bowiem zarazem pokusa zabójstwa go. Paradoksalnie - na co zwraca uwagę autorka - okazuje się, że ta sama słabość i bezbronność, która objawia się w epifanii twarzy, jest tym, co kusi i zaprasza do przemocy. Tak więc spotkanie z Innym otwiera dwie możliwe postawy wobec Drugiego: bycie dobrym i bycie złym.

Problem zła w filozofii Levinasa został potraktowany przez Magdalenę Kozak z perspektywy zagadnienia Dobra. Zło okazuje się bowiem nierozerwalnie $\mathrm{z}$ nim związane. Autorka prezentuje Levinasa koncepcję podmiotowości etycznej polegającą na byciu wybranym przez Dobro do odpowiedzialności bezgranicznej aż po substytucję, która czyni z podmiotu zakładnika Drugiego. Analizy zawarte w pracy w dużej mierze sprowadzają się do prezentowania koncepcji Dobra Levinasa, z tego względu, iż jedną z tez autorki dotyczącą zła jest twierdzenie, że polega ono na odstąpieniu od Dobra, co oznacza nieodpowiedzenie na wezwanie płynące $\mathrm{z}$ twarzy Innego. Tylko bowiem poprzez bycie dobrym można uniknąć bycia złym.

Książkę zamyka rozdział poświęcony próbie krytycznej oceny Levinasowskiej wizji zła. Magdalena Kozak stara się w nim rozważyć, czy ontologia słusznie może być utożsamiana ze złem. Stawia również pytanie, czy wizja bycia - dla - Innego aż po substytucję jest w ogóle możliwa i czy realizowanie jej nie sprowadza się w praktyce do zniszczenia siebie samego, a dobru nie przysługuje totalizująca moc, którą przecież Levinas krytykował u Hegla. Pytania te są rozważane poprzez przywołanie głosów takich komentatorów Levinasa, jak Derrida, Tischner czy współczesnych, lecz mało znanych w polskim kręgu, Sebbaha i Critchley’a.

Nawet jeśli można mieć zastrzeżenia do zaprezentowanej przez Magdalenę Kozak interpretacji zła jako zła moralnego w wymiarze samej konstytucji podmiotu w filozofii Levinasa, to przedstawione analizy zasługują na uwage chociażby w celu ich weryfikacji. Praca stawia w nowym świetle nie tylko samą filozofię Levinasa, bo rozpatrywaną pod kątem zła, lecz również po- 
przez wypunktowanie silnie narzucających się wątpliwości odnośnie do prezentowanej przez Levinasa koncepcji Dobra. Publikacja niewątpliwie spełnia swój zasadniczy cel, szeroko omawiając zagadnienie zła występujące w całym pisarskim dorobku Levinasa, uwzględniając przy tym kontekst historyczno-biograficzny. Książka została uzupełniona bibliografią, nie posiada jednak indeksu.

Ewa Witkowska 